\title{
OPEN Potentially toxic elements pollution in road deposited sediments around the active smelting industry of Korea
}

\author{
Hyeryeong Jeong ${ }^{1,2}$, Jin Young $\mathrm{Choi}^{1} \&$ Kongtae $\mathrm{Ra}^{1,2 \bowtie}$
}

Potentially toxic elements (PTEs) were investigated in the different sizes of road deposited sediments (RDS) around the active smelting industry to understand their sources and to assess the pollution and ecological risk levels. The highest PTEs concentrations was shown near the raw materials import port and the smelting facilities. The fine particles of RDS showed extremely high PTEs concentrations. $\mathrm{Zn}$ has the highest mean concentration in the $<63 \mu \mathrm{m}$ particle size of RDS, followed by $\mathrm{Pb}>\mathrm{Cu}>\mathrm{As}>\mathrm{Cr}>\mathrm{Ni}>\mathrm{Cd}>\mathrm{Hg}$. The $\mathrm{PTEs}$ concentrations of this study were the highest values compared to the soils around the smelter and the RDS in urban and industrial areas in the world. This indicates that these PTEs pollution in RDS were mainly attributed to the transportation of raw materials for the smelting industry. According to nemerow pollution index calculation, RDS at all sampling sites with particles of less than $250 \mathrm{~mm}$ was seriously polluted with PTEs. The ecological risk was also found to be very high in all RDS fractions and highly toxic elements such as $\mathrm{Cd}, \mathrm{Pb}$ and $\mathrm{Hg}$ pose extremely risk. Given the total amounts PTEs in the road surface, it is necessary to apply RDS removal management plan to reduce the PTEs pollution.

Road infrastructure and transportation are important components of urban areas and have enabled the rapid development of industrialization and urbanization. Road deposited sediments (RDS) are highly contaminated with potentially toxic elements (PTEs) by various traffic and industry-related sources such as vehicular exhaust and non-exhaust sources, atmospheric deposition and surrounding soil erosion and spill of industrial raw materials during transportation ${ }^{1-6}$. Thus, roads are often a prominent point-source and non-point source of dissolved and sediment-associated PTEs ${ }^{6-10}$. The particle size distribution of RDS is a very important factor as it determines the behavior and mobility of the particles and shows the highest concentration of PTEs in fine particles ${ }^{11-13}$. Environmental concern related to RDS is that RDS containing high concentrations of PTEs on the road surface adversely affects the surrounding environments as well as human health ${ }^{14-16}$. The fine fractions of RDS are readily transported to the surrounding aquatic environments by stormwater runoff. Many studies reported that the fine particle $\left(<44 \mu \mathrm{m}^{17},<63 \mu \mathrm{m}^{18},<125 \mu \mathrm{m}^{6}\right)$ largely contributed of total suspended solids (TSS) load in stormwater runoff from urban and industrial areas. The finer RDS are also re-suspended by strong winds and the high-speed movement of the vehicles, therefore, PTEs bound to fine particles of RDS and surrounding soils can enter the human body via inhalation, ingestion and dermal absorption ${ }^{19-21}$. Our previous study reported that $14.3-15.8 \mathrm{~g} /$ $\mathrm{m}^{2}(<63 \mu \mathrm{m})$ and $3.2-4.2 \mathrm{~g} / \mathrm{m}^{2}(>1000 \mu \mathrm{m})$ of RDS in urban area accumulate on the road surface in Korea ${ }^{22}$. On road surface, RDS are deposited of $11.7 \mathrm{~g} / \mathrm{m}^{2}$ in urban area $^{17}$ and $174.6 \mathrm{~g} / \mathrm{m}^{2}$ in industrial area ${ }^{6}$. Industrial areas are characterized by a higher accumulation of road dust than urban areas. In Korea, the amounts and concentrations of PTEs in fine particle of RDS were much higher in industrial area than in urban areas ${ }^{5,22,23}$. Given the total length of road, a huge amount of PTEs would have been accumulated in road surface. Of course, PTEs pollution in industrial RDS is subjected to the complex influence of traffic and industrial activities. Lanzerstorfer ${ }^{13}$ reported that the PTEs concentrations in urban RDS can be used as a useful indicator for environmental pollution. The potential sources of PTEs can be identified by evaluating the PTEs concentrations in RDS from different land use types and the elemental ratios of them ${ }^{11,24-26}$. Although there are very few RDS studies in industrial areas compared to urban areas, the study of PTEs concentration in RDS from the industrial area will make it possible to differentiate between transport and industrial activities. The objectives of this study are to: (1) evaluate the PTEs

\footnotetext{
${ }^{1}$ Marine Environmental Research Center, Korea Institute of Ocean Science and Technology (KIOST), Busan 49111, Korea. ${ }^{2}$ Department of Ocean Science (Oceanography), KIOST School, University of Science and Technology (UST), Daejeon 34113, Korea. ${ }^{\varpi}$ email: ktra@kiost.ac.kr
} 


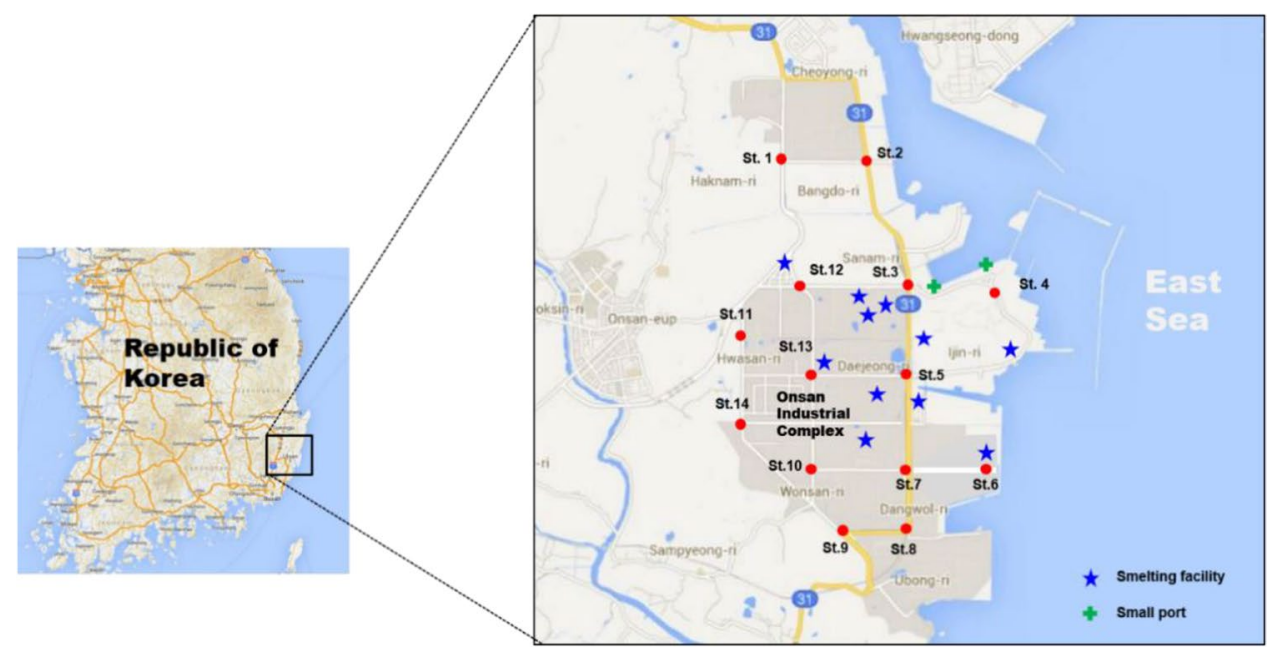

Figure 1. Locations of sampling sites for road deposited sediments from Onsan industrial complex including the smelter of Korea. Figure created using Microsoft Office PowerPoint 2016 based on Google Maps (available at https://www.google.com/maps).

pollution levels of different RDS sizes in the industrial area where the smelting industry is active; (2) identify the pollution sources of PTEs; (3) assess the potential ecological posed by PTEs.

\section{Materials and methods}

Sampling and PTEs analysis. Total of 14 RDS samples were collected from Onsan Industrial complex including several smelting facilities of Korea (Fig. 1) during December 2013 following a dry weather periods of about 10 days. Average temperature, humidity, and wind speed were $4.3{ }^{\circ} \mathrm{C}, 52.0 \% \mathrm{rh}$, and $6.7 \mathrm{~m} / \mathrm{s}$ respectively. The RDS were collected in four and more sub-sampling for each site using a cordless vacuum cleaner (DC-35, Dyson Co., UK) with $0.5 \mathrm{~m} \times 0.5 \mathrm{~m}$ space along the curb of the road. This vacuum cleaner can collect dust with high efficiency using powerful centrifugal forces spin. After collecting RDS samples, the vacuum cleaner was disassembled and cleaned, and the parts that were difficult to clean were replaced with new ones to prevent cross-contamination. Each RDS sample were sieved individually using $<63 \mu \mathrm{m}, 63-125 \mu \mathrm{m}, 125-250 \mu \mathrm{m}, 250-$ $500 \mu \mathrm{m}, 500-1000 \mu \mathrm{m},>1000 \mu \mathrm{m}^{27}$ by using vibratory sieve shaker (Analysette 3 pro, Fritsch Co., Germany) with nylon sieves in laboratory. Each fraction of RDS sample was weighted, pulverized (Pulverisette 6, Fritsch Co., Germany) and stored separately into pre-acid cleaned polyethylene bottle until metal analysis. The weight (g) of each RDS size fraction accounted for 7.3\% (<63 $\mu \mathrm{m}), 11.8 \%(63-125 \mu \mathrm{m}), 23.2 \%(125-250 \mu \mathrm{m}), 31.8 \%$ $(250-500 \mu \mathrm{m}), 17.1 \%(500-1000 \mu \mathrm{m})$, and $8.9 \%(>1000 \mu \mathrm{m})$ of the total RDS samples. About $0.1 \mathrm{~g}$ of each ground and homogenized RDS sample was weighted in Teflon digestion vessel added with high purity (Ultra100 grade, Kanto Chemical, Japan) of $\mathrm{HNO}_{3}, \mathrm{HF}$ and $\mathrm{HClO}_{4}$ on a hot plate at $180{ }^{\circ} \mathrm{C}$ for $24 \mathrm{~h}$ for total digestion. After evaporation and redissolution with $2 \% \mathrm{HNO}_{3}$, heavy metals of $\mathrm{Cr}, \mathrm{Ni}, \mathrm{Cu}, \mathrm{Zn}, \mathrm{As}, \mathrm{Cd}$ and $\mathrm{Pb}$ were analyzed using inductively coupled plasma mass spectrometry (ICP-MS, iCAP-Q, Thermo Scientific Co., Germany). $\mathrm{Hg}$ was determined using $\mathrm{Hg}$ analyzer (Hydra-C, Leeman Labs, USA) based on the USEPA 7473 method. The blanks and duplicate measurements were performed for quality control. Two types of certified reference materials for MESS-4 and PACS-3 (National Research Council, Canada) were used to check data accuracy. Recoveries ranged between $96.4 \%$ and $102.1 \%$ for MESS- 4 and between $93.9 \%$ and $106.0 \%$ for PACS-3, respectively.

Pollution level assessment. The geo-accumulation index $\left(\mathrm{I}_{\text {geo }}\right)$, proposed by $\mathrm{Muller}^{28}$, can be used to assess the pollution level of individual metal using the following equation:

$$
\mathrm{I}_{\text {geo }}=\log _{2}\left(\mathrm{C}_{\mathrm{i}} /\left(1.5 \times \mathrm{B}_{\mathrm{i}}\right)\right)
$$

where $C_{i}$ and $B_{i}$ are the concentrations of RDS samples and the geochemical background values ${ }^{29}, 1.5$ is the background correction efficient. $I_{\text {geo }}$ value were classified into seven categories ${ }^{28,30}$.

The nemerow index $\left(\mathrm{P}_{\mathrm{N}}\right)$ are widely used to make a comprehensive evaluation of the pollution levels of heavy metals in soils and sediments ${ }^{31-35}$ and was calculated using the following equation:

$$
P_{N}=\sqrt{\frac{\left(\frac{1}{n} \sum_{i=1}^{n} P I_{i}^{2}\right)+(\operatorname{Max} P I)^{2}}{2}}
$$

where PI represent a single pollution index of metal $i, \mathrm{PI}_{\mathrm{i}}=\mathrm{C}_{\mathrm{i}} / \mathrm{S}_{\mathrm{i}} \cdot \mathrm{C}_{\mathrm{i}}$ is the measured concentration of each metal $i$. The calculated results of $\mathrm{P}_{\mathrm{N}}$ using the geological background value can be overestimated the magnitude of metal pollution ${ }^{36}$. Therefore, the soil quality guideline values were used in this study to better reflect the comprehensive pollution level of heavy metals in Korea. $S_{\mathrm{i}}$ is the soil pollution concern standard for road and factory 
site in Korea and its values (mg/kg) of $\mathrm{Cr}^{6+}, \mathrm{Ni}, \mathrm{Cu}, \mathrm{Zn}, \mathrm{As}, \mathrm{Cd}, \mathrm{Pb}$ and $\mathrm{Hg}$ were 40, 500, 2000, 2000, 200, 60, 700 and 20 , respectively ${ }^{37}$. In Korea, soil samples are sieved with a $150 \mu \mathrm{m}$ mesh. PTEs in soils $(<150 \mu \mathrm{m})$ are analyzed and compared with the soil pollution concern standard. In case of $\mathrm{Cr}$, in Korea soil quality guideline, the concentration of $\mathrm{Cr}^{6+}$ is recommended. $\mathrm{Lazo}^{38}$ reported that the content of $\mathrm{Cr}^{6+}$ accounts for more than $90 \%$ of total $\mathrm{Cr}$ in the contaminated area. Therefore, the application of total $\mathrm{Cr}$ concentration instead of $\mathrm{Cr}^{6+}$ of this study did not significantly affect the results of pollution evaluation for eight metals using $\mathrm{P}_{\mathrm{N}}$. This index divides pollution into five grades ${ }^{39}$.

Potential ecological risk assessment. Potential ecological risk index (PER), proposed by Hakanson ${ }^{40}$ can be used to assess the risk of eight metals based on their toxicity response using the following equations:

$$
\begin{aligned}
E_{r}^{i} & =T_{r}^{i} \times\left(C_{i} / B_{i}\right) \\
P E R & =\sum_{i=1}^{n} E_{r}^{i}
\end{aligned}
$$

where $C_{i}$ and $B_{i}$ were the same as those in $I_{\text {geo }}$ calculation. $E_{r}^{i}$ is the single factor ecological risk degree for PTEs. $\mathrm{T}_{\mathrm{r}}^{\mathrm{i}}$ is the toxic response factor for a single metal pollution $(\mathrm{Hg}=40, \mathrm{Cd}=30, \mathrm{As}=10, \mathrm{Cu}=\mathrm{Ni}=\mathrm{Pb}=5, \mathrm{Cr}=2$, $\mathrm{Zn}=1)^{40,41}$. $\mathrm{E}_{\mathrm{r}}^{\mathrm{i}}$ were classified into five classes ${ }^{42}$ and the PER value were classified into four classes ${ }^{40,43}$. PASW statistics program (version 18) was used for the Pearson's correlation analysis and principal component analysis (PCA) to extract correlation among PTEs in this study. Hierarchical cluster analysis (HCA) was also performed to understand the relationship between different size fractions of RDS.

Grain size fraction loading. The grain size fraction loading $\left(\mathrm{GSF}_{\text {loading }}\right)$ was calculated using the relative mass loads of PTEs in the six particle size fractions of the RDS, which is expressed as follows:

$$
G S F_{\text {loading }}=100 \times\left[\frac{X_{i} \times G S_{i}}{\sum_{i=1}^{6} X_{i} \times G S_{i}}\right]
$$

where $\mathrm{X}_{\mathrm{i}}$ is the concentration of PTEs by particle size fraction separated from each RDS sample, and $\mathrm{GS}_{\mathrm{i}}$ is the mass percentage of each particle size fraction. The sum of the $\mathrm{GSF}_{\text {loading }}$ values for each RDS sample is always $100 \%{ }^{44}$.

\section{Results and discussion}

PTEs contents in different sizes of RDS. The minimum, maximum and mean values of the total RDS amount and $\mathrm{Cr}, \mathrm{Ni}, \mathrm{Cu}, \mathrm{Zn}, \mathrm{As}, \mathrm{Cd}, \mathrm{Pb}$, and $\mathrm{Hg}$ concentrations are shown in Table 1. Crustal elements such as $\mathrm{Al}, \mathrm{Fe}$, and Li showed no significant difference depending on different sizes of RDS (Table S1). The Cu, Zn, As, $\mathrm{Cd}, \mathrm{Pb}$, and $\mathrm{Hg}$ concentrations significantly increased with decreasing in particle size of RDS (Fig. 2). Mean PTE concentrations in the fine particle size $(<63 \mu \mathrm{m})$ of RDS was $5.0(\mathrm{Cr}) \sim 55.5(\mathrm{Zn})$ times higher than those in the large particle size $(>1000 \mu \mathrm{m})$. The mean concentration of RDS $(63 \mu \mathrm{m})$ was highest for $\mathrm{Zn}$ at $34,592 \mathrm{mg} / \mathrm{kg}$, followed by $\mathrm{Pb}(13,561)>\mathrm{Cu}(7071)>\mathrm{As}(961)>\mathrm{Cr}(596)>\mathrm{Ni}(364)>\mathrm{Cd}(225)>\mathrm{Hg}$ (17). The $\mathrm{Cr}$ and Ni concentrations in the fine particle size $(<63 \mu \mathrm{m})$ showed highest values at $\mathrm{S} 6$ site, but the highest concentrations for $\mathrm{Cu}$, $\mathrm{Zn}$, As, Cd were observed in S4 and S5 sites which the smelting facilities exist (Fig. S1 and S2).

The study area, Onsan industrial complex, has concentrated non-ferrous metal production industry of Korea. There are many smelting facilities in operation that produces $1.2 \mathrm{Mt}$ of nonferrous metals annually, including $\mathrm{Cu}$, $\mathrm{Zn}, \mathrm{Cd}$ and $\mathrm{Pb}$. The largest smelter in this study region produces high-purity ingots for $\mathrm{Cu} 25,800 \mathrm{t}, \mathrm{Zn} 650,100$ $\mathrm{t}$, and $\mathrm{Pb} 413,000 \mathrm{t}$. Garmash (1985) ${ }^{45}$ found that nonferrous metal smelters are more contaminated with $\mathrm{Zn}, \mathrm{Pb}$, and Cd in soils than iron smelters. The amount of RDS accumulated on road surface in the study area is higher than that in urban areas. There are raw material import ports and outdoor raw material storages for smelting industry on the north of S4 site.

The PCA results indicated that the two principal components explaining $72.498 \%$ of the total variance (Table S2). Kaiser-Meyer-Olkin (KMO) value was found to be 0.745 and Bartlett's test value was $0(p<0.001)$, confirming to be suitable for PCA analysis. PC1 was dominated by $\mathrm{Cu}, \mathrm{Zn}, \mathrm{As}, \mathrm{Cd}$, and $\mathrm{Pb}$, accounting for $50.034 \%$ of the total variance (Table S2). RDS of this study is significantly correlated with among $\mathrm{Cu}, \mathrm{Zn}, \mathrm{As}$, $\mathrm{Cd}$, and $\mathrm{Pb}$. Raw materials are transported using a large truck. The highest PTEs concentrations were observed in all particle sizes of RDS around the smelting facilities, indicating that raw materials for the smelting industry were spilled onto the road surface during transportation. PC2 consisted of $\mathrm{Cr}$ and Ni, explaining $22.464 \%$ of the total variance (Table S2). A high correlation between $\mathrm{Cr}$ and $\mathrm{Ni}$ was observed. $\mathrm{Cr}$ and $\mathrm{Ni}$ are discharged from furnaces during the manufacture of iron and steel, or also used in alloy manufactures such as stainless steel and chromium plating ${ }^{46}$. Jo et al. ${ }^{47}$ reported that $\mathrm{Cr}$ and $\mathrm{Ni}$ contamination in roadside soil was affected by traffic and industrial activities in Korea. Generally, $\mathrm{Cr}$ is used in vehicle parts including metal plating, wrist pins, and connecting rods ${ }^{48}$. Adamiec et al. ${ }^{3}$ reported that the urban and motorway road dust were contaminated with $\mathrm{Cr}$ from the abrasion of brake and alloys (wrist pins and connecting rods). In this study, the contamination of $\mathrm{Cr}$ and $\mathrm{Ni}$ was lower than that of other metals, indicating that $\mathrm{Cr}$ and $\mathrm{Ni}$ contamination was not directly related to the smelting industry. The highest concentrations of $\mathrm{Cr}$ and Ni were observed at $\mathrm{S} 11$ site, with high traffic activity connected to the highway. Therefore, $\mathrm{Cr}$ and $\mathrm{Ni}$ were more related to traffic activities in this area.

Hierarchical cluster analysis was also conducted to understand the relationship among the different sizes of RDS. The dendrogram of the different particle sizes of RDS shows two cluster groups (Fig. S3). Group 1 comprises 


\begin{tabular}{|c|c|c|c|c|c|c|c|c|c|}
\hline Size $(\mu \mathrm{m})$ & $\operatorname{RDS}\left(\mathrm{g} / \mathrm{m}^{2}\right)$ & $\mathrm{Cr}(\mathrm{mg} / \mathrm{kg})$ & $\mathrm{Ni}(\mathrm{mg} / \mathrm{kg})$ & $\mathrm{Cu}(\mathrm{mg} / \mathrm{kg})$ & $\mathrm{Zn}(\mathrm{mg} / \mathrm{kg})$ & As (mg/kg) & $\mathrm{Cd}(\mathrm{mg} / \mathrm{kg})$ & $\mathrm{Pb}(\mathrm{mg} / \mathrm{kg})$ & $\mathrm{Hg}(\mathrm{mg} / \mathrm{kg})$ \\
\hline \multicolumn{10}{|l|}{$>1000$} \\
\hline Min & 4 & 51 & 26 & 71 & 256 & 3 & 0.9 & 65 & 0.01 \\
\hline Max & 298 & 220 & 68 & 3212 & 3735 & 100 & 20.9 & 1685 & 27.9 \\
\hline Mean & 104 & 120 & 46 & 623 & 623 & 46 & 6.3 & 470 & 2.5 \\
\hline SD & 92 & 56 & 15 & 846 & 846 & 28 & 5.0 & 418 & 7.4 \\
\hline \multicolumn{10}{|l|}{$500-1000$} \\
\hline Min & 30 & 76 & 28 & 249 & 1177 & 10 & 2.0 & 209 & 0.1 \\
\hline $\operatorname{Max}$ & 688 & 2262 & 1156 & 7537 & 16,579 & 187 & 45.9 & 4083 & 54.6 \\
\hline Mean & 200 & 410 & 166 & 2243 & 7167 & 67 & 11.5 & 1483 & 4.5 \\
\hline SD & 193 & 552 & 287 & 2016 & 5186 & 49 & 11.2 & 1107 & 14.4 \\
\hline \multicolumn{10}{|l|}{$250-500$} \\
\hline Min & 85 & 80 & 23 & 294 & 1518 & 25 & 2.2 & 240 & 0.1 \\
\hline $\operatorname{Max}$ & 1104 & 435 & 187 & 8477 & 20,034 & 341 & 64.2 & 6264 & 62.4 \\
\hline Mean & 373 & 249 & 111 & 2782 & 8646 & 92 & 18.8 & 2171 & 5.5 \\
\hline SD & 330 & 107 & 50 & 2170 & 5708 & 85 & 16.9 & 1560 & 16.4 \\
\hline \multicolumn{10}{|l|}{$125-250$} \\
\hline Min & 72 & 100 & 23 & 284 & 1279 & 12 & 3.7 & 268 & 0.3 \\
\hline Max & 704 & 678 & 556 & 10,875 & 26,279 & 374 & \begin{tabular}{|l|}
157.9 \\
\end{tabular} & 10,311 & \begin{tabular}{|l|}
69.6 \\
\end{tabular} \\
\hline Mean & 272 & 285 & 147 & 2978 & 6743 & 141 & 38.0 & 3072 & 7.2 \\
\hline SD & 223 & 138 & \begin{tabular}{|l|}
127 \\
\end{tabular} & 2708 & 6135 & 110 & 39.4 & 2718 & \begin{tabular}{|l|l|}
18.1 \\
\end{tabular} \\
\hline \multicolumn{10}{|l|}{ 63-125 } \\
\hline Min & 53 & 199 & 54 & 348 & 2152 & 59 & 7.4 & 463 & 0.4 \\
\hline Max & 335 & 921 & 645 & 16,511 & 112,751 & 840 & 644.1 & 23,536 & 46.4 \\
\hline Mean & 138 & 476 & 222 & 5265 & 19,620 & 330 & 128.7 & 7924 & 8.9 \\
\hline SD & 94 & 217 & 153 & 4258 & 28,085 & 204 & 162.6 & 6927 & 11.9 \\
\hline \multicolumn{10}{|l|}{$<63$} \\
\hline Min & 28 & 200 & 106 & 975 & \begin{tabular}{|l|l|}
4400 \\
\end{tabular} & 110 & \begin{tabular}{|l|}
17.6 \\
\end{tabular} & 1253 & 1.2 \\
\hline Max & 197 & 1416 & \begin{tabular}{|l|}
1081 \\
\end{tabular} & 18,873 & \begin{tabular}{|l|l}
166,457 \\
\end{tabular} & 2721 & 975.6 & 44,667 & \begin{tabular}{|l|}
45.1 \\
\end{tabular} \\
\hline Mean & 85 & 596 & 364 & 7071 & 34,592 & 961 & 225.1 & 13,561 & 17.0 \\
\hline SD & 50 & 368 & 299 & 5552 & 44,856 & 744 & 278.6 & 12,438 & 13.2 \\
\hline
\end{tabular}

Table 1. Minimum, maximum, and mean values of PTEs in the different sizes of road deposited sediments of this study.

two particle size fractions $(<125 \mu \mathrm{m})$ with significant PTEs contamination. Group 2 corresponded to the particle size of $<125 \mu \mathrm{m}$ with moderate PTEs contamination.

The PTEs concentrations of this study are higher than those of RDS in urban area of Korea ${ }^{10,22,23}$, indicating that RDS of industrial area are mainly influenced by industrial activities related to transportation of raw materials for smelting industry. In particular, the concentration of PTEs in the fine $(<63 \mu \mathrm{m})$ size of RDS in this study were the highest values compared to the RDS in urban cities ${ }^{3,22,49-51}$ and the soils around the smelter ${ }^{52-62}$ in the world (Table 2).

Pollution assessment in industrial RDS. Based on PTEs concentrations in different particle sizes of RDS, quantification of PTEs pollution was conducted using the $\mathrm{I}_{\text {geo }}$ and $\mathrm{P}_{\mathrm{N}}$ indices. Comparison of mean $\mathrm{I}_{\text {geo }}$ values in different particles size of RDS is shown in Table 3. RDS of less than $63 \mu \mathrm{m}$ had the highest $\mathrm{I}_{\text {geo }}$ value for all PTEs. The mean of $\mathrm{I}_{\text {geo }}$ values of PTEs for $<63 \mu \mathrm{m}$ size of RDS are arranged in the following order: $\mathrm{Cd}>\mathrm{Pb}>$ $\mathrm{Zn}>\mathrm{Hg}>\mathrm{Cu}>\mathrm{As}>\mathrm{Ni}>\mathrm{Cr}$. The mean values of $\mathrm{I}_{\text {geo }}$ for $\mathrm{Cr}$ and $\mathrm{Ni}$ show that the large particle $(>125 \mu \mathrm{m})$ is not polluted, but the fine particle $(<125 \mu \mathrm{m})$ is characterized as medium to heavily pollution. The mean values of $\mathrm{I}_{\text {geo }}$ showed that the RDS less than $1000 \mathrm{~mm}$ have an extremely heavy pollution for $\mathrm{Cu}, \mathrm{Zn}, \mathrm{Cd}$, and $\mathrm{Pb}$. For the case of As and $\mathrm{Hg}$, the mean values of $\mathrm{I}_{\text {geo }}$ in RDS less than $125 \mu \mathrm{m}$ exceeded 5 corresponding extremely heavy pollution, and RDS larger than $500 \mu \mathrm{m}$ had relatively low pollution levels.

The results of nemerow index $\left(\mathrm{P}_{\mathrm{N}}\right)$ showed that the mean values were in the descending order of less than $63 \mu \mathrm{m}(23.2)>63-125 \mu \mathrm{m}(12.8)>125-250 \mu \mathrm{m}(5.8)>250-500 \mu \mathrm{m}(4.7)>500-1000 \mu \mathrm{m}(7.5)>$ above $1000 \mu \mathrm{m}$ (2.2). As the RDS size decreased, the $P_{N}$ value increases. Generally, fine particle sizes of RDS have high concentrations of PTEs than coarse particles ${ }^{6,17}$. For the RDS size less than $250 \mu \mathrm{m}, \mathrm{P}_{\mathrm{N}}$ values are significantly exceeding 3 at all sampling sites, representing serious polluted with PTEs (Fig. 3). 

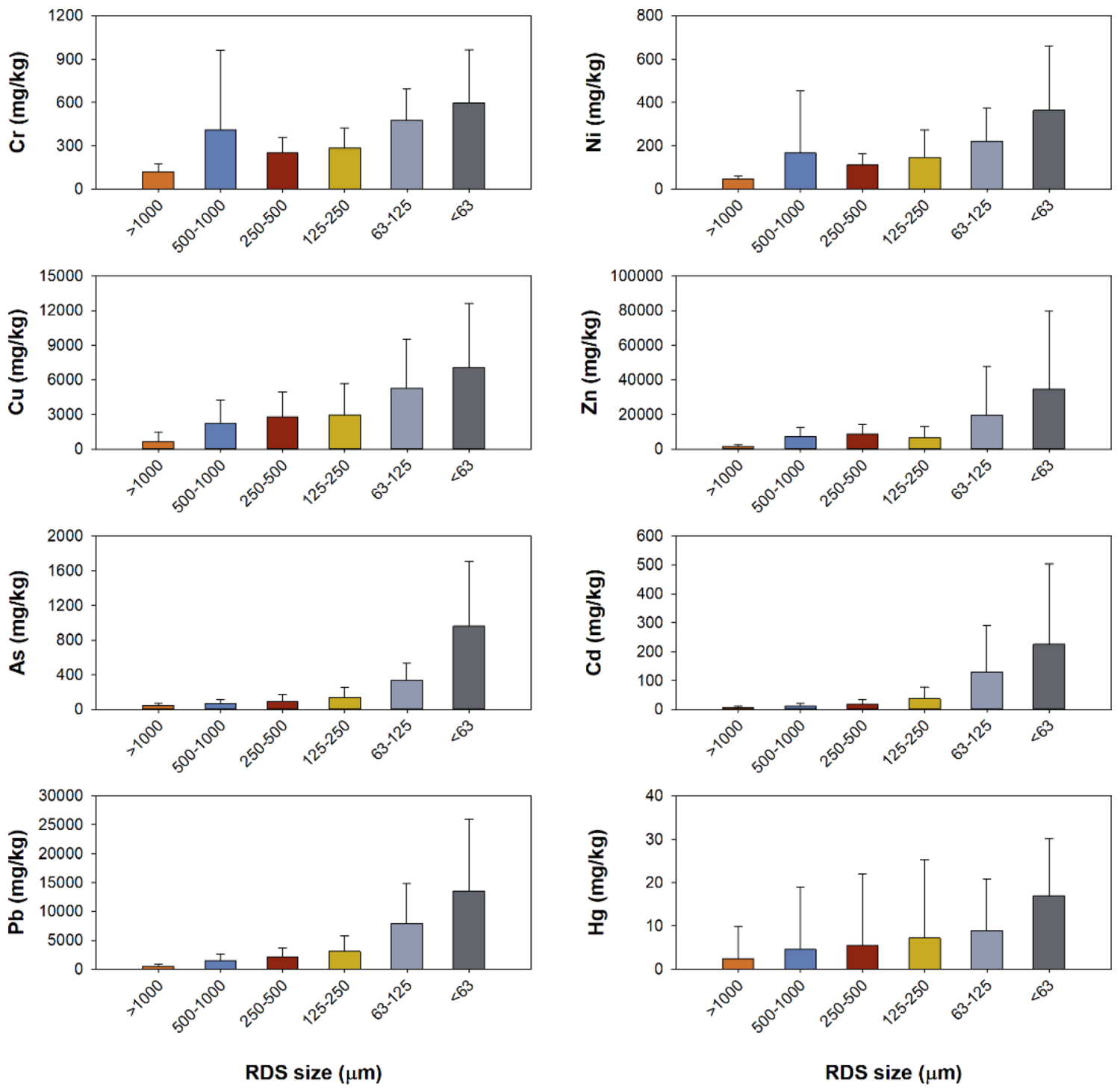

Figure 2. Comparison of mean PTEs concentrations $(\mathrm{mg} / \mathrm{kg})$ with standard deviation in the different sizes of road deposited sediments of this study.

Figure 4 shows the spatial distribution of $\mathrm{P}_{\mathrm{N}}$ values in the different sizes of RDS. The spatial distribution of $\mathrm{P}_{\mathrm{N}}$ values for $<125 \mu \mathrm{m}$ was high around the smelting facilities, but relatively low at the sampling sites away from the smelters. The high pollution degree of RDS $(<125 \mu \mathrm{m})$ indicates that the fine particles of RDS are attached to the tires according to vehicle transport and spreads through the entire road surface. Additionally, the chimney of smelter and vehicle emissions are other potential sources of PTEs in RDS. Bennett and Knapp ${ }^{63}$ reported that the median particle size emitted from $\mathrm{Cu}, \mathrm{Zn}$, and $\mathrm{Pb}$ smelter ranged from 0.1 to $2.2 \mu \mathrm{m}$. The particle size emitted by engine combustion of a vehicle is very small in the size range of $20-150 \mathrm{~nm}^{64}$. Given the RDS amounts and spatial distribution of PTEs deposited in the road surface and, the major cause of PTEs contamination in RDS of this study is probably due to spillage and diffusion of raw ore minerals during transportation rather than particulate emissions from smelters.

Ecological risk assessment in industrial RDS. The results of single factor ecological risk degree $\left(\mathrm{E}_{\mathrm{r}}^{\mathrm{i}}\right)$ are presented in Table 4. The highest mean $E_{r}^{i}$ value was observed for $C d(75,044)$ in $<63 \mu \mathrm{m}$ of $\operatorname{RDS}$ and the lowest $E_{r}^{i}$ value was observed for $\mathrm{Cr}(2.6)$ in $>1000 \mu \mathrm{m}$ of RDS. Similar to the PTEs concentrations, the single ecological risk was higher as the particle size of RDS decreased. The mean of single factor ecological risk degree $\left(\mathrm{E}_{\mathrm{r}}^{\mathrm{i}}\right)$ values of $\mathrm{Cr}$ and $\mathrm{Ni}$ in all particle sizes was less than 40 , which indicated that $\mathrm{Cr}$ and $\mathrm{Ni}$ concentrations of RDS correspond to the low ecological risk level. The mean values of $\mathrm{E}_{\mathrm{r}}^{\mathrm{i}}$ of $\mathrm{Cd}$ were the highest among those of all PTEs for all sampling sites and ranged from $2095(>1000 \mu \mathrm{m})$ to $75,044(<63 \mu \mathrm{m})$, indicating extremely 


\begin{tabular}{|c|c|c|c|c|c|c|c|c|c|}
\hline $\mathrm{Cr}$ & $\mathrm{Ni}$ & $\mathrm{Cu}$ & $\mathbf{Z n}$ & As & Cd & $\mathrm{Pb}$ & $\mathrm{Hg}$ & Sample types & References \\
\hline $596(470)$ & $364(264)$ & $7071(5074)$ & $34,592(18,362)$ & $961(623)$ & $225.1(122.8)$ & $13,561(9791)$ & $17.0(13.2)$ & $<63 \mu \mathrm{m}, \mathrm{RDS}$ & This study $(\mathrm{N}=14)$ \\
\hline $167(156)$ & $50(49)$ & $160(139)$ & $907(955)$ & $15.7(14.0)$ & $1.4(1.1)$ & $207(181)$ & $0.04(0.05)$ & $<63 \mu \mathrm{m}, \mathrm{RDS}$ & Urban, Korea $(\mathrm{N}=5)^{22}$ \\
\hline \multirow[t]{3}{*}{$841(637)$} & $246(268)$ & $193(166)$ & $2982(2739)$ & $16.0(15.7)$ & $2.1(1.6)$ & $221(159)$ & $0.21(0.16)$ & $<63 \mu \mathrm{m}, \mathrm{RDS}$ & Industrial, Korea ${ }^{49}$ \\
\hline & 52.1 & 345 & 1271 & & 2.3 & 223 & & $<75 \mu \mathrm{m}$ RDS & Urban, Korea ${ }^{50}$ \\
\hline & & 124 & 630 & & 38 & 350 & & $<63 \mu \mathrm{m}, \mathrm{RDS}$ & Urban, Spain $^{51}$ \\
\hline \multirow[t]{6}{*}{182} & 109 & 287 & 1829 & & 0.9 & 456 & & $<20 \mu \mathrm{m}, \mathrm{RDS}$ & Motorway, Poland $(\mathrm{N}=3)^{3}$ \\
\hline & & 78 & 1062 & & 5.54 & 363 & & Top soil $(0-30 \mathrm{~cm})$ & $\mathrm{Pb} / \mathrm{Zn}$ smelter, Australia ${ }^{52}$ \\
\hline & & & $7366(8285)$ & & $102(120)$ & $2401(2340)$ & & Top soil $(0-36 \mathrm{~cm})$ & $\mathrm{Pb} / \mathrm{Zn}$ smelter, France $(\mathrm{N}=3)^{53}$ \\
\hline & & 4011 & 1503 & 333 & & 1503 & & Soil $(10-30 \mathrm{~cm})$ & Cu smelter, Poland ${ }^{54}$ \\
\hline & $(10.2)$ & (13.6) & $(2175)$ & $(81)$ & $(14.8)$ & $(545)$ & & Top soil $(0-10 \mathrm{~cm})$ & $\begin{array}{l}\mathrm{Pb} / \mathrm{Zn} \text { smelter, Poland } \\
(\mathrm{N}=137)^{55}\end{array}$ \\
\hline & & 161 & 3630 & & 54.5 & 1740 & & Top soil $(0-15 \mathrm{~cm})$ & $\mathrm{Pb} / \mathrm{Zn}$ smelter, $\mathrm{UK}(\mathrm{N}=5)^{56}$ \\
\hline \multirow[t]{4}{*}{227} & 247 & 666 & 5917 & & 138 & 4892 & & Top soil $(0-20 \mathrm{~cm})$ & $\mathrm{Pb} / \mathrm{Zn}$ smelter, Bulgaria ${ }^{57}$ \\
\hline & & 118 & 2558 & 76 & 31.7 & 953 & 2.27 & Top soil $(0-20 \mathrm{~cm})$ & $\mathrm{Pb} / \mathrm{Zn}$ smelter, China $(\mathrm{N}=9)^{58}$ \\
\hline & & 39 & 597 & & 22.1 & 992 & & Top soil $(0-5 \mathrm{~cm})$ & $\mathrm{Pb} / \mathrm{Zn}$ smelter, China $(\mathrm{N}=12)^{59}$ \\
\hline & & $(100)$ & $(1100)$ & $(100)$ & $(7.6)$ & $(2600)$ & $(0.85)$ & Surface soil & $\begin{array}{l}\mathrm{Pb} / \mathrm{Zn} \text { smelter, Kosovo } \\
(\mathrm{N}=30)^{60}\end{array}$ \\
\hline \multirow[t]{2}{*}{$160(160)$} & $54(54)$ & $44(41)$ & $280(210)$ & $9.8(9.2)$ & $7.7(6.4)$ & $220(210)$ & $0.25(0.28)$ & Top soil $(0-5 \mathrm{~cm})$ & $\begin{array}{l}\mathrm{Pb} / \mathrm{Zn} \text { smelter, Macedonia } \\
(\mathrm{N}=159)^{61}\end{array}$ \\
\hline & & $4575(4550)$ & $3380(3550)$ & $1780(1650)$ & $128(122)$ & $5925(5990)$ & & Top soil $(0--10 \mathrm{~cm})$ & $\begin{array}{l}\mathrm{Cu} / \mathrm{Pb} \text { smelter, Namibia } \\
(\mathrm{N}=4)^{62}\end{array}$ \\
\hline
\end{tabular}

Table 2. Comparison between the average (median value in parenthesis) PTEs concentrations (mg/kg) in the road deposited sediment $(<63 \mu \mathrm{m})$ and those in the other published data.

potential risk levels $\left(\mathrm{E}_{\mathrm{r}}^{\mathrm{i}}>320\right)$. $\mathrm{Hg}$ has the second highest $\mathrm{E}_{\mathrm{r}}^{\mathrm{i}}$ values and exceed 320 in all particle sizes of RDS, showing extremely potential risk. For $\mathrm{Cu}$ and $\mathrm{Pb}$, the mean of $\mathrm{E}_{\mathrm{r}}^{\mathrm{i}}$ values were also obtained extremely potential risk except for the large RDS size $>1000 \mu \mathrm{m}$. Generally, the $\mathrm{E}_{\mathrm{r}}^{\mathrm{i}}$ values were ranked in the following order: $\mathrm{Cd}>\mathrm{H}$ $\mathrm{g}>\mathrm{Pb}>\mathrm{Cu}>\mathrm{As}>\mathrm{Zn}>\mathrm{Ni}>\mathrm{Cr}$. The mean of PER values, the comprehensive ecological risk of eight PTEs, ranged from $4434(>1000 \mu \mathrm{m})$ to $96,435(<63 \mu \mathrm{m})$ and the fine particle was 21.7 times higher that large particle. The PER values exceeded 600, indicating very high ecological risk for all studied sites and particle size of RDS except for $>1000 \mu \mathrm{m}$ at S11 site (Fig. 3).

PTEs loads in RDS on the road surface around the active smelting industry. The mean of RDS amount in road surface were 104 for $>1000 \mu \mathrm{m}, 200$ for $500-1000 \mu \mathrm{m}, 373$ for $250-500 \mu \mathrm{m}, 272$ for $125-$ $250 \mu \mathrm{m}, 138$ for $63-125 \mu \mathrm{m}, 85 \mathrm{~g} / \mathrm{m}^{2}$ for $<63 \mu \mathrm{m}$, respectively (Table 1 ). Spatial distribution of amounts in different particle sizes of RDS is shown in Fig. S4. The amount of RDS with particle size of $250-500 \mu \mathrm{m}$ was the most abundant in this study. We also calculated the PTEs loads and the contribution of each particle size fraction using GSF $_{\text {loading }}$ (Fig. 5). A significant amount of PTEs $\left(21,872 \mathrm{mg} / \mathrm{m}^{2}\right)$ has accumulated on the road surface in industrial area. The each PTEs load in industrial RDS was much higher than in urban RDS ${ }^{17}$. The order of the sum PTEs loading value in RDS for all measured PTEs was less than $63 \mu \mathrm{m}(26.3 \%)>250-500 \mu \mathrm{m}$ $(23.6 \%)>63-125 \mu \mathrm{m}(22.5 \%)>125-250 \mu \mathrm{m}(16.7 \%)>500-1000 \mu \mathrm{m}(9.6 \%)>$ above $1000 \mu \mathrm{m}(1.3 \%)$. Among the

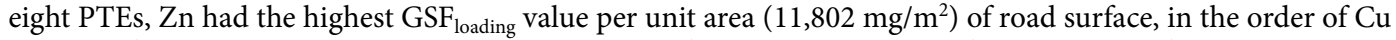
$(4984)>\mathrm{Pb}(4177)>\mathrm{Cr}(370)>\mathrm{As}(215)>\mathrm{Ni}(169)>\mathrm{Cd}(47)>\mathrm{Hg}$ (4). Given the GSF $\mathrm{Fading}_{\text {and PTEs concentra- }}$ tions, particles of 250-500 mm showed the highest contribution for $\mathrm{Cr}, \mathrm{Ni}, \mathrm{Cu}$ and $\mathrm{Zn}$, but the mean values of $\mathrm{GSF}_{\text {loading }}$ were dominant in the $<63 \mu \mathrm{m}$ fraction for $\mathrm{As}, \mathrm{Cd}, \mathrm{Pb}$, and $\mathrm{Hg}$ (Fig. 6).

The mean of PTEs loading in RDS has accumulated about $48.8 \%$ in the $<125 \mu \mathrm{m}$ fraction, which is readily washed from stormwater runoff and is difficult to remove by road cleaning. Jeong et al. ${ }^{6}$ evaluated the particle size distribution in total suspended solids (TSS) of industrial runoff and found that $<125 \mu \mathrm{m}$ particle size in TSS ranged from $53.9 \%$ to $98.7 \%$. The particle size of $<125 \mu \mathrm{m}$ RDS accounted for $35.1 \%, 37.1 \%, 40.6 \%, 43.1 \%$, $59.8 \%, 62.9 \%, 53.7 \%$, and 63.2 of $\mathrm{Cr}, \mathrm{Ni}, \mathrm{Cu}, \mathrm{Zn}, \mathrm{As}, \mathrm{Cd}, \mathrm{Pb}$, and $\mathrm{Hg}$ in total RDS, respectively. Our previous study proposed that RDS make a significant contribution of PTEs pollution to total suspended particles in stormwater runoff at industrial areas 6 .

Road surface is a pollution hotspot where enormous PTEs accumulate in RDS and transport to surrounding environments via stormwater runoff and wind. The curb is the most RDS-accumulated area on a road surface s,65. $^{6}$. Therefore, road and street sweeping technique is recognized as being an efficient and important tool to reduce stormwater and atmosphere pollution derived from the $\mathrm{RDS}^{66-68}$. Tobin and Brinkmann ${ }^{66}$ reported that the rotary 


\begin{tabular}{|c|c|r|c|c|c|c|c|c|}
\hline Size $(\boldsymbol{\mu m})$ & $\mathbf{C r}$ & $\mathbf{N i}$ & $\mathbf{C u}$ & $\mathbf{Z n}$ & $\mathbf{A s}$ & $\mathbf{C d}$ & $\mathbf{P b}$ & $\mathbf{H g}$ \\
\hline$>1000$ & -0.3 & -0.7 & 3.0 & 3.6 & 2.3 & 5.1 & 3.7 & 1.4 \\
\hline $500-1000$ & 1.0 & 0.5 & 5.2 & 5.7 & 2.9 & 5.9 & 5.4 & 2.8 \\
\hline $250-500$ & 0.7 & 0.4 & 5.5 & 6.0 & 3.3 & 6.6 & 6.0 & 3.6 \\
\hline $125-250$ & 0.9 & 0.7 & 5.7 & 5.7 & 3.8 & 7.5 & 6.4 & 4.8 \\
\hline $63-125$ & 1.7 & 1.4 & 6.5 & 6.8 & 5.2 & 9.1 & 7.6 & 6.0 \\
\hline$<63$ & 1.9 & 2.0 & 7.0 & 7.6 & 6.6 & 9.9 & 8.5 & 7.3 \\
\hline
\end{tabular}

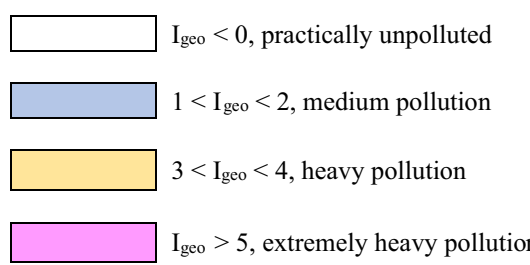

$0<\mathrm{I}_{\text {geo }}<1$, unpolluted to medium polluted

$2<$ Igeo $_{\text {}}<3$, medium to heavy pollution

$4<$ Igeo $_{1}<5$, heavy to extremely heavy pollution

Table 3. Mean values of geo-accumulation index $\left(\mathrm{I}_{\text {geo }}\right)$ of PTEs in the different size of road deposited sediments.
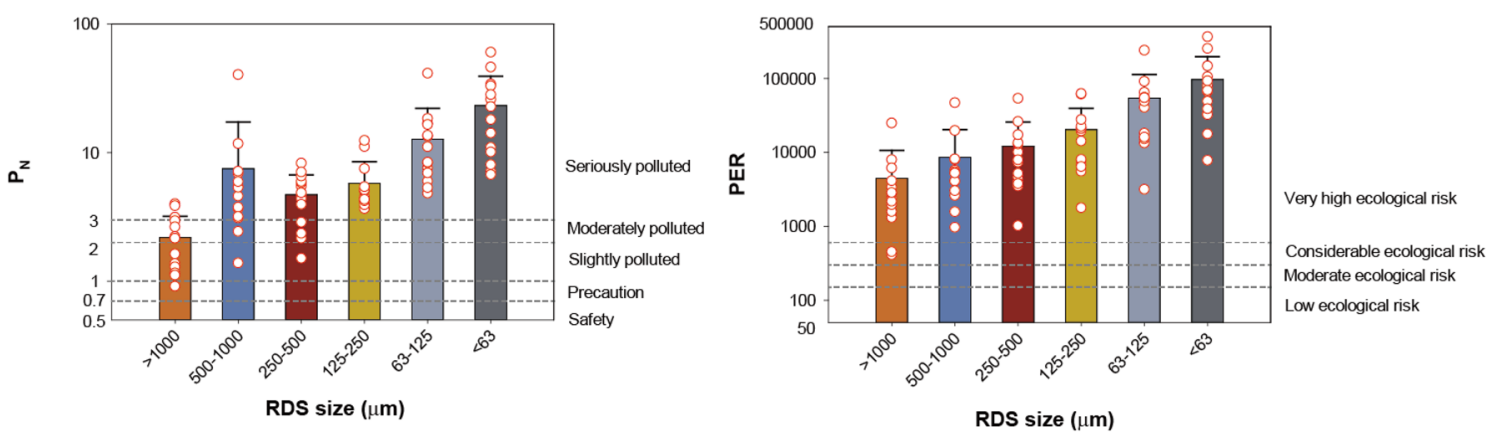

Figure 3. Comparison of nemerow index $\left(\mathrm{P}_{\mathrm{N}}\right)$ and potential ecological risk index (PER) of the difference sizes of road deposited sediments of this study.

brush sweeper is more efficient than a vacuum sweeper for large sediments in the road, but the vacuum sweeper can be effective in removing fine particles. Kim et al. ${ }^{67}$ estimated the removal efficiency of RDS by sweeping with vacuum-assisted rotary brush sweeper in Korea. They found that the mean of reduction in the load of RDS and heavy metals of highway by sweeping was $61.1 \%$ and $48 \%$, respectively. The removal of particles $(>63 \mu \mathrm{m})$ is greatly improving the highway runoff quality by vacuum-related rotary brush sweeper of RDS, indicating that the sweeping is more efficient for large particles. Given the total length of entire road, the amount of RDS and PTEs concentrations on the road surface, huge amounts of PTEs can be accumulated in the RDS of the industrial area. RDS had the highest concentrations of PTEs in fine particles that are difficult to remove by road sweeping. In Korea, RDS is periodically removed by various types of road cleaning vehicles in urban cities, but road cleaning is not performed in industrial areas. Our results show that road cleaning in industrial areas can remove enormous PTEs that affect the environments and human health. RDS management strategies for fine particles are required to reduce the PTEs pollution and the ecological environmental risk.

\section{Conclusions}

RDS is highly polluted by various pollutants, especially PTEs, and has received much attention as one of the important pollution sources in the terrestrial, coastal, and atmospheric environments as well as human health problems. We studied the concentrations and loadings of PTEs in different particle sizes of RDS around the active smelting industry to figure out their pollution source and to assess the pollution and potential ecological risk levels. PTE concentration in RDS increased with decreasing in particle size and the fine size $(<63 \mu \mathrm{m})$ of RDS was heavily polluted with PTEs. Mean metal concentrations $(\mathrm{mg} / \mathrm{kg})$ in the fine size $(<63 \mu \mathrm{m})$ were on the order of $\mathrm{Zn}$ $(34,592)>\mathrm{Pb}(13,561)>\mathrm{Cu}(7071)>\mathrm{As}(961)>\mathrm{Cr}(596)>\mathrm{Ni}(364)>\mathrm{Cd}(225)>\mathrm{Hg}(17)$. These concentrations of 
$>1000 \mu \mathrm{m}$

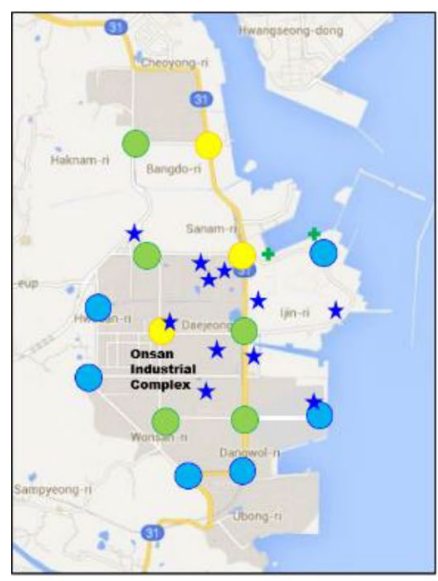

125-250 $\mu \mathrm{m}$

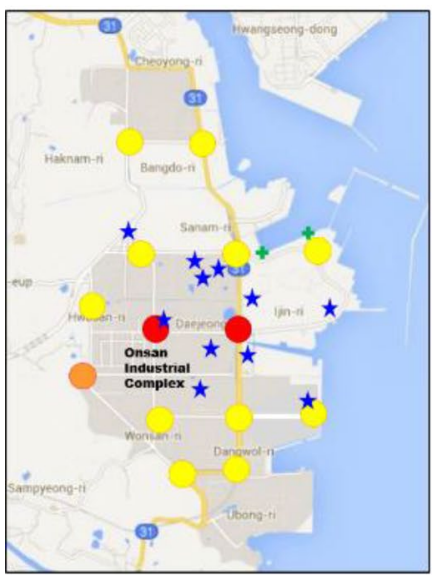

Safety

Precaution
$500-1000 \mu \mathrm{m}$

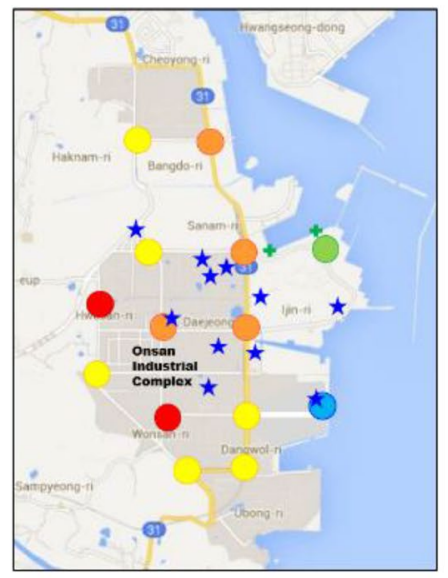

63-125 $\mu \mathrm{m}$

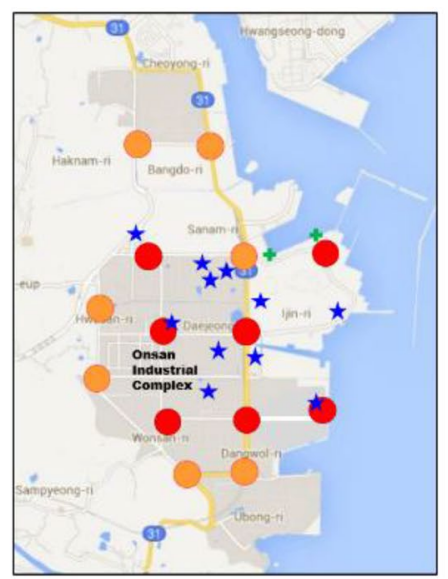

Moderately polluted
$250-500 \mu \mathrm{m}$

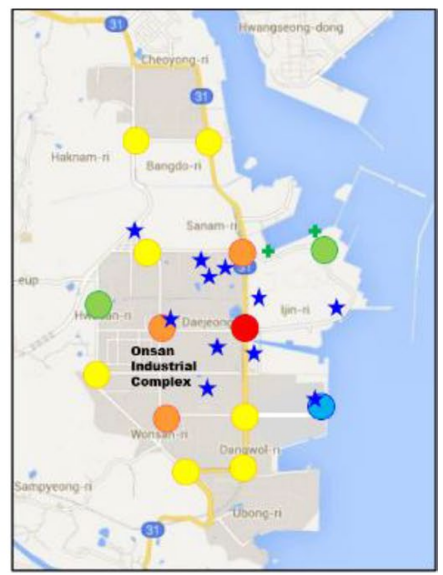

$<63 \mu \mathrm{m}$

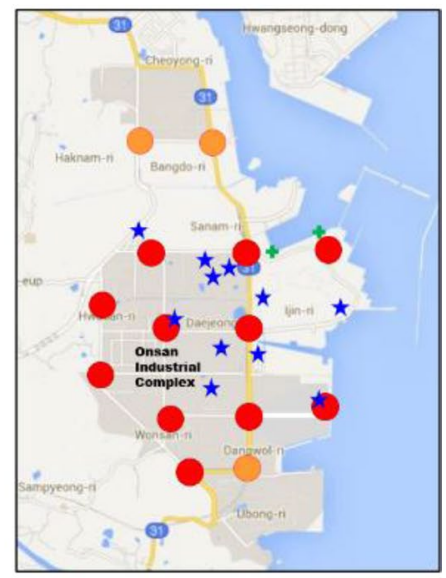

Seriously polluted

Figure 4. Spatial distribution of nemerow index $\left(\mathrm{P}_{\mathrm{N}}\right)$ values in the different sizes of road deposited sediments. Blue star symbol means a smelting facility. Figure created using Microsoft Office PowerPoint 2016 based on Google Maps (available at https://www.google.com/maps).

\begin{tabular}{|c|c|c|c|c|c|c|c|c|}
\hline Size $(\boldsymbol{\mu m})$ & $\mathbf{C r}$ & $\mathbf{N i}$ & $\mathbf{C u}$ & $\mathbf{Z n}$ & $\mathbf{A s}$ & $\mathbf{C d}$ & $\mathbf{P b}$ & $\mathbf{H g}$ \\
\hline$>1000$ & 2.6 & 4.9 & 111 & 25 & 96 & 2095 & 138 & 1961 \\
\hline $500-1000$ & 8.9 & 17.7 & 400 & 107 & 139 & 3843 & 436 & 3621 \\
\hline $250-500$ & 5.4 & 11.8 & 497 & 129 & 192 & 6273 & 638 & 4397 \\
\hline $125-250$ & 6.2 & 15.6 & 532 & 101 & 294 & 12667 & 903 & 5767 \\
\hline $63-125$ & 10.3 & 23.6 & 940 & 293 & 688 & 42900 & 2331 & 7110 \\
\hline$<63$ & 12.9 & 38.7 & 1263 & 516 & 2002 & 75044 & 3988 & 13570 \\
\hline
\end{tabular}

$\square \mathrm{E}_{\mathrm{r}}^{\mathrm{i}}<40$, low risk

$\square 80<\mathrm{E}_{\mathrm{r}}^{\mathrm{i}}<160$, considerable risk $\mathrm{E}_{\mathrm{r}}^{\mathrm{i}}>320$, extremely risk

Table 4. Mean values of single factor ecological risk degree $\left(\mathrm{E}_{\mathrm{r}}^{\mathrm{i}}\right)$ of PTEs in the different size of road deposited sediments. 

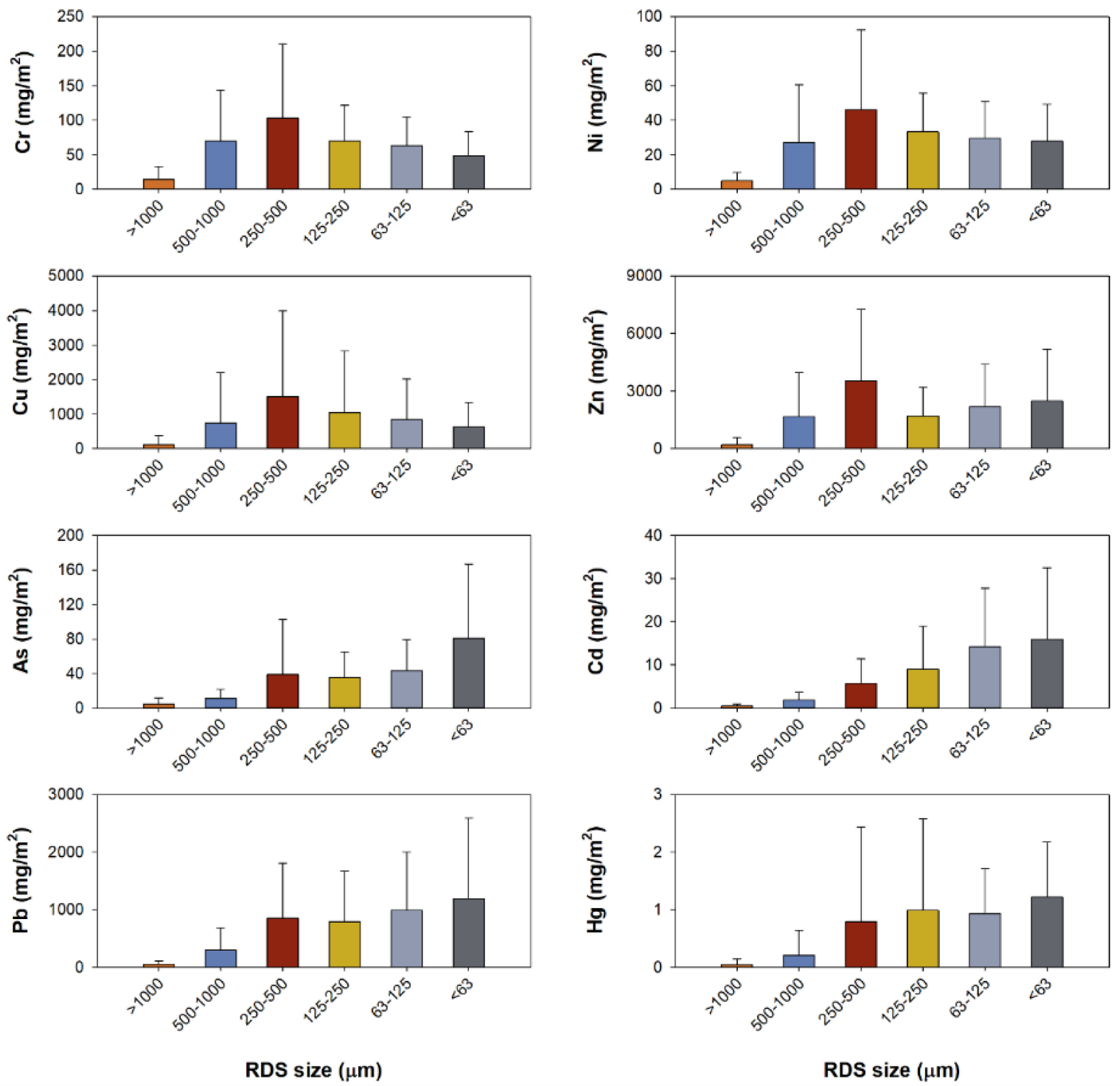

Figure 5. Comparison of mean PTEs loads $\left(\mathrm{mg} / \mathrm{m}^{2}\right)$ with standard deviation in the different sizes of road deposited sediments of this study.

PTEs in this study were the highest values compared to the soils around the smelter and the RDS in urban cities in the world. The PTEs in RDS could be derived from both particulate emissions from chimney and truck spills during the transportation of raw ore for smelting activity. The spatial distribution of PTEs for $<125 \mu \mathrm{m}$ was high around the smelting facilities, but relatively low at the sampling sites away from the smelters. Our results indicate that the PTEs in RDS might be affected by spillage and diffusion of raw ore minerals during transportation rather than particulate emission from the smelters. Road surface around the smelter has a significant amount of RDS accumulated with a mean of $21,678 \mathrm{mg} / \mathrm{m}^{2}$ compared to urban areas. $\mathrm{Cr}, \mathrm{Ni}, \mathrm{Cu}, \mathrm{Zn}, \mathrm{As}, \mathrm{Cd}, \mathrm{Pb}$, and $\mathrm{Hg}$ were accumulated per unit area in amounts of $370,169,4984,11,802,215,47,4177$, and $4 \mathrm{mg} / \mathrm{m}^{2}$ in the road surface of the study area. The relative contributions of $\mathrm{Zn}, \mathrm{As}, \mathrm{Cd}, \mathrm{Pb}$ and $\mathrm{Hg}$ in the fraction $(<125 \mu \mathrm{m})$ that could transport to the surrounding environments via runoff and resuspension accounted for $39.6 \%(\mathrm{Zn}), 57.9 \%$ (As), 63.8\% (Cd), 52.3\% (Pb) and 51.3\% (Hg) of the total RDS. Given the amount of PTEs deposited on the road surface, it is necessary to apply an RDS removal management plan to reduce the PTEs pollution. 


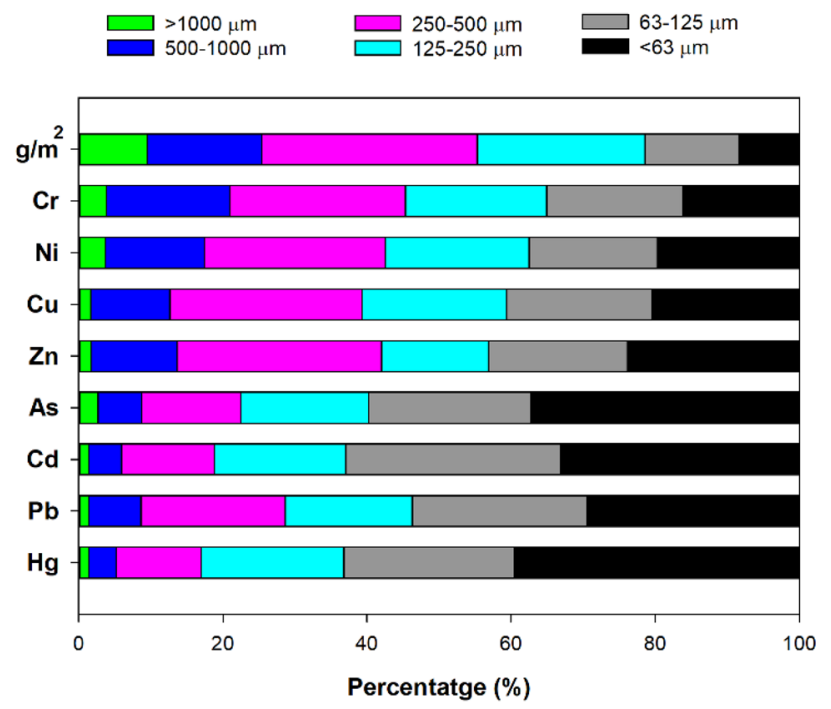

Figure 6. PTEs loading percentages of different sizes of road deposited sediments in this study.

\section{Data availability}

All Data for this study are available from the corresponding author on request.

Received: 12 November 2020; Accepted: 25 February 2021

Published online: 31 March 2021

\section{References}

1. Adachi, K. \& Tainosho, Y. Characterization of heavy metal particle embedded in tire dust. Environ. Int. 30, 1009-1017 (2004).

2. Shafer, M. M. et al. Chemical speciation of vanadium in particulate matter emitted from diesel vehicles and urban atmospheric aerosols. Environ. Sci. Technol. 46, 189-195 (2012).

3. Adamiec, E., Jarosz- Krzemińska, E. \& Wieszała, R. Heavy metals from non-exhaust vehicle emissions in urban and motorway road dusts. Environ. Monit. Assess. 188, 369 (2016).

4. Loganathan, P., Vigneswaran, S. \& Kandasamy, J. Road-deposited sediment pollutants: A critical review of their characteristics, source apportionment, and management. Crit. Rev. Environ. Sci. Technol. 43, 1315-1348 (2013).

5. Baensch-Baltruschat, B., Kocher, B., Stock, F. \& Reifferscheid, G. Tyre and road wear particles (TRWP)—A review of generation, properties, emissions, human health risk, ecotoxicity, and fate in the environment. Sci. Total Environ. 733, 137823 (2020).

6. Jeong, H., Choi, J. Y., Lee, J., Lim, J. \& Ra, K. Heavy metal pollution by road-deposited sediments and its contribution to total suspended solids in rainfall runoff from intensive industrial areas. Environ. Pollut. 265, 115028 (2020).

7. Zhao, H., Yin, C., Chen, M. \& Wang, W. Risk assessment of heavy metals in street dust particles to a stream network. Soil Sediment Contam. 18, 173-183 (2009).

8. Zhao, H. et al. Is the wash-off process of road-deposited sediment source limited or transport limited?. Sci. Total. Environ. 563-564, 62-70 (2016).

9. Yuen, J. Q. et al. Accumulation of potentially toxic elements in road deposited sediments. J. Environ. Monit. 101, 151-163 (2012).

10. Jeong, H. et al. Characterization of the contribution of road deposited sediments to the contamination of the close marine environment with trace metals: Case of the port city of Busan (South Korea). Mar. Pollut. Bull. 161, 111717 (2020).

11. Zhu, W., Bian, B. \& Li, L. Heavy metal contamination of road-deposited sediments in a medium size of China. Environ. Monit. Assess. 147, 171-181 (2008).

12. Zhao, H., Wang, X. \& Li, X. Quantifying grain-size variability of metal pollutants in road-deposited sediments using the coefficient of variation. Int. J. Environ. Res. Public Health 14, 850 (2017).

13. Lanzerstorfer, C. Heavy metals in the finest size fractions of road-deposited sediments. Environ. Pollut. 239, 522-531 (2018).

14. Davis, B. \& Birch, G. Comparison of heavy metal loads in stormwater runoff from major and minor urban roads using pollutants yield rating curves. Environ. Pollut. 158, 2541-2545 (2010).

15. Du, Y. et al. Health risk assessment of heavy metals in road dusts in urban parks of Beijing, China. Procedia Environ. Sci. 18, 299-309 (2013).

16. Roy, S. et al. Ecological and human health risk assessment of heavy metal contamination in road dust in the National Capital Territory (NCT) of Delhi, India. Environ. Sci. Pollut. Res. 26, 30413-30425 (2019).

17. Zhao, H., Li, X., Wang, X. \& Tian, D. Grain size distribution of road-deposited sediments and its contribution of heavy metal pollution in urban runoff in Beijing, China. J. Hazard. Mater. 183, 203-210 (2010).

18. Hilliges, R., Endres, M., Tiffert, A., Brenner, E. \& Marks, T. Characterization of road runoff with regards to seasonal variations, particle size distribution and the correlation of fine particles and pollutants. Water Sci. Technol. 75, 1169-1176 (2016).

19. Charlesworth, S., De Miguel, E. \& Ordóñez, A. A review of the distribution of particle trace elements in urban terrestrial environments and its application to considerations of risk. Environ. Geochem. Health 33, 103-123 (2011).

20. Li, H. H. et al. Pollution characteristics and risk assessment of human exposure to oral bioaccessibility of heavy metals via urban street dusts from different functional areas in Chengdu, China. Sci. Total Environ. 586, 1076-1084 (2017).

21. Wu, L. et al. Seasonal levels, sources, and health risks of heavy metals in atmospheric $\mathrm{PM}_{2.5}$ from four functional areas of Nanjing city, eastern China. Atmosphere 10, 419 (2019).

22. Jeong, H., Choi, J. Y. \& Ra, K. Study on heavy metal pollution sources to Shihwa lake: characteristics of heavy metal in sizefractionated road dust from urban area and the impacts to marine environments. J. Korean Soc. Mar. Environ. Energy 23, 70-80 (2020) ((In Korean)). 
23. Choi, J. Y. et al. Source identification and implications of heavy metals in urban roads for the coastal pollution in a beach town, Busan, Korea. Mar. Pollut. Bull. 161, 111724 (2020).

24. Das, R. et al. Trace element composition of $\mathrm{PM}_{2.5}$ and $\mathrm{PM}_{10}$ from Kolkata-a heavily polluted Indian Metropolis. Atmos. Pollut. Res. 6, 742-750 (2015).

25. Hwang, H. M., Fiala, M. J., Park, D. \& Wade, T. L. Review of pollutants in urban road dust and stormwater runoff: Part 1. Heavy metals released from vehicles. Int. J. Urban Sci. 20, 334-360 (2016).

26. Aguilera, A., Armendariz, C., Quintana, P., García-Oliva, F. \& Bautista, F. Influence of land use and road type on the elemental composition of urban dust in a Mexican Metropolitan Area. Pol. J. Environ. Stud. 28, 1535-1547 (2019).

27. Wentworth, C. K. A scale of grade and class terms for clastic sediments. J. Geol. 30, 377-392 (1992).

28. Muller, G. Index of geoaccumulation in sediments of the Rhine River. GeoJournal 2, 108-118 (1969).

29. Rudnick, R.I. \& Gao, S. Composition of the continental crust. In: Rudnick, R.L., editor. The Crust, Elsevier, pp. 1-64 (2003).

30. Liu, J., Wu, J., Feng, W. \& Li, X. Ecological risk assessment of heavy metals in water bodies around typical copper mines in China. Int. J. Environ. Res. Public Health 17, 4315 (2020).

31. Nemerow, N.L. Stream, Lake, Estuary, and Ocean Pollution (1991).

32. Yang, Z., Lu, W., Long, Y., Bao, X. \& Yang, Q. Assessment of heavy metals contamination in urban topsoil from Changchun City, China. J. Geochem. Explor. 108, 27-38 (2011).

33. Nezhad, M. T. K., Tabatabaii, S. M. \& Gholami, A. Geochemical assessment of steel smelter-impacted urban soils, Ahvaz, Iran. J. Geochem. Explor. 152, 91-109 (2015).

34. Huang, L. et al. Heavy metals distribution, sources, and ecological risk assessment in Huixian wetland, South China. Water 12, $431(2020)$.

35. Men, C. et al. Source-specific ecological risk analysis and critical source identification of heavy metals in road dust in Beijing, China. J. Hazard. Mater. 388, 121763 (2020).

36. Hong-gui, D., Teng-feng, G., Ming-hui, L. \& Xu, D. Comprehensive assessment model on heavy metal pollution in soil. Int. J. Electrochem. Sci. 7, 5286-5296 (2012).

37. Ministry of Government Legislation. Korea soil quality standard of heavy metals in soil environment conservation act (Law No. 16613) (2019)

38. Lazo, P. Determination of $\mathrm{Cr}(\mathrm{VI})$ in environmental samples evaluating $\mathrm{Cr}(\mathrm{VI})$ impact in a contaminated area. J. Int. Environ. Appl. Sci. 42, 207-213 (2009).

39. Jie-liang, C., Zhou, S. \& You-Wei, Z. Assessment and mapping of environmental quality in agricultural soils of Zhejiang Province, China. J. Environ. Sci. 19, 50-54 (2007).

40. Hakanson, L. An ecological risk index for aquatic pollution control. A sedimentological approach. Water Res. 14, 975-1001 (1980).

41. Lu, X. et al. Risk assessment of toxic metals in street dust from a medium-sized industrial city of China. Ecotoxicol. Environ. Saf. 106, 154-163 (2014).

42. Zhao, W. et al. Levels and ecological risk assessment of metals in soils from a typical e-waste recycling region in southeast China. Ecotoxicol. 24, 1947-1960 (2015).

43. Feng, Y., Bao, Q., Yunpeng, C., Lizi, Z. \& Xiao, X. Stochastic potential ecological risk model for heavy metal contamination in sediment. Ecol. Indic. 102, 246-251 (2019).

44. Sutherland, R. A. Lead in grain size fractions of road-deposited sediment. Environ. Pollut. 121, 229-237 (2003).

45. Garmash, G. A. Distribution of heavy metals in soils near metallurgical plants. Soviet Soil Sci. 17, 80-85 (1985)

46. Wang, K. et al. A comprehensive emission inventory of multiple air pollutants from iron and steel industry in China: Temporal trends and spatial variation characteristics. Sci. Total Environ. 559, 7-14 (2016).

47. Jo., M., Lee, M. \& Kim, K.R. Investigation of soil $\mathrm{Cr}$ and Ni contamination in different land uses and tracing the source of contamination. Korean J. Soil Sci. Fert. 53, 510-518 (2020) (in Korean).

48. Zgłobicki, W., Telecka, M. \& Skupiński, S. Assessment of short-term changes in street dust pollution with heavy metals in Lublin (E Poland)-Levels, sources and risks. Environ. Sci. Pollut. Res. 26, 35049-35060 (2019).

49. Jeong, H., Choi, J. Y. \& Ra, K. Assessment of metal pollution of road-deposited sediments and marine sediments around Gwangyang Bay, Korea. J. Korean Soc. Oceanogr. 25, 42-53 (2020) ((in Korean)).

50. Duong, T. T. T. et al. Heavy metal contamination of road dust at the downtown area in the Metropolitan city of Ulsan, Korea. J. Environ. Manag. 92, 554-562 (2011).

51. Zafra, C. A., Temprano, J. \& Tejero, I. Distribution of the concentration of heavy metals associated with the sediment particles accumulated on road surface. Environ. Technol. 32, 997-1008 (2011).

52. Kachenko, A. G. \& Singh, B. Heavy metals contamination in vegetables grown in urban and metal smelter contaminated sites in Australia. Water Air Soil Pollut. 169, 101-123 (2006).

53. Denaix, L., Semlali, R. M. \& Douay, F. Dissolved and colloidal transport of $\mathrm{Cd}, \mathrm{Pb}$, and $\mathrm{Zn}$ in a silt loam affected by atmospheric industrial deposition. Environ. Pollut. 114, 29-38 (2001).

54. Kierczak, J. et al. Environmental impact of the historical Cu smelting in the Rudawy Janowickie Mountains (south-western Poland). J. Geochem. Explor. 124, 183-194 (2013).

55. Verner, J. F., Ramsey, M. H., Helios-Rybicka, E. \& Jêdrzejczyk, B. Heavy metal contamination of soils around a Pb-Zn smelter in Bukowno, Poland. Appl. Geochem. 11, 11-16 (1996).

56. Nahmani, J., Hodson, M. E. \& Black, S. Effects of metals on life cycle parameters of the earthworm Eisenia fetida exposed to fieldcontaminated, metal-polluted soils. Environ. Pollut. 149, 44-58 (2007).

57. Bacon, J. R. \& Dinev, N. S. Isotopic characterisation of lead in contaminated soils from the vicinity of a non-ferrous metal smelter near Plovdiv, Bulgaria. Environ. Pollut. 134, 247-255 (2005).

58. Li, Z. et al. Mercury and other metal and metalloid soil contamination near a $\mathrm{Pb} / \mathrm{Zn}$ smelter in east Hunan province, China. Appl. Geochem. 26, 160-166 (2011).

59. Cui, Y. J. et al. Transfer of metals from soil to vegetables in an area near a smelter in Nanning, China. Environ. Pollut. 30, 785-791 (2004)

60. Šajn, R., Aliu, M., Stafilov, T. \& Alijagić, J. Heavy metal contamination of topsoil around a lead and zinc smelter in Kosovska Mitrovica/Mitrovicë, Kosovo/Kosovë. J. Geochem. Explor. 134, 1-16 (2013).

61. Stafilov, T. et al. Heavy metal contamination of topsoils around a lead and zinc smelter in the Republic of Macedonia. J. Hazard. Mater. 175, 896-914 (2010).

62. Mihaljevič, M. et al. Trace elements and the lead isotopic record in marula (Sclerocarya birrea) tree rings and soils near the Tsumeb Smelter, Namibia. Water Air Soil Pollut. 226, 177 (2015).

63. Bennett, R. L. \& Kanpp, K. T. Characterization of particulate emissions from non-ferrous smelters. JAPCA 39, 169-174 (1989).

64. Agarwal, A. K., Gupta, T., Lukose, J. \& Singh, A. P. Particulate characterization and size distribution in the exhaust of a gasoline homogeneous charge compression ignition engine. Aerosol Air Qual. Res. 15, 504-516 (2015).

65. Gustafsson, M. et al. Road dust load dynamics and influencing factors for six winter seasons in Stockholm, Sweden. Atmos. Environ. X 2, 100014 (2019).

66. Tobin, G. A. \& Brinkmann, R. The effectiveness of street sweepers in removing pollutants from road surfaces in Florida. J. Environ. Sci. Health 37, 1687-1700 (2002). 
67. Kim, D. G., Jeong, K. \& Ko, S. O. Removal of road deposited sediments by sweeping and its contribution to highway runoff quality in Korea. Environ. Technol. 35, 2546-2555 (2014).

68. Polukarova, M. et al. Organic pollutants, nano- and microparticles in street sweeping road dust and washwater. Environ. Int. 135, $105337(2020)$

\section{Acknowledgements}

The authors declare that they have no conflict of interest. This research was supported by grant (PE99912) from Korea Institute of Ocean Science and Technology (KIOST).

\section{Author contributions}

H.J and K.R conceptualized, conducted the PTEs measurements, prepared all figures and tables and wrote original manuscript. J.C performed RDS sampling and reviewed the manuscript. All authors reviewed the manuscript.

\section{Competing interests}

The authors declare no competing interests.

\section{Additional information}

Supplementary Information The online version contains supplementary material available at https://doi.org/ 10.1038/s41598-021-86698-X.

Correspondence and requests for materials should be addressed to K.R.

Reprints and permissions information is available at www.nature.com/reprints.

Publisher's note Springer Nature remains neutral with regard to jurisdictional claims in published maps and institutional affiliations.

(c) (i) Open Access This article is licensed under a Creative Commons Attribution 4.0 International License, which permits use, sharing, adaptation, distribution and reproduction in any medium or format, as long as you give appropriate credit to the original author(s) and the source, provide a link to the Creative Commons licence, and indicate if changes were made. The images or other third party material in this article are included in the article's Creative Commons licence, unless indicated otherwise in a credit line to the material. If material is not included in the article's Creative Commons licence and your intended use is not permitted by statutory regulation or exceeds the permitted use, you will need to obtain permission directly from the copyright holder. To view a copy of this licence, visit http://creativecommons.org/licenses/by/4.0/.

(C) The Author(s) 2021 